\title{
An Assessment of Covid-19 Factors which Influence Non-Compliance of Payments in Respect of Social Security Contributions in Ghana
}

\author{
Samuel Nii Attoh Abbey \\ Ph.D. in Management, Texila American University, Ghana
}

\begin{abstract}
COVID-19 has been wreaking havoc on the business world for nearly two years, with most industries experiencing a significant decline in revenue. The major statutory agency in charge of regulating employee pension schemes in Ghana, the Social Security National Insurance Trust (SSNIT) Ghana, has also seen a drop in monthly contributions. As a result, the goal of the study was to see how the COVID19 epidemic is affecting non-compliance with Ghana's Social Security Monthly Contribution Payments. The study used a random sampling methodology to select 6 out of 19 decentralized governance structures in Accra, after which a purposive selection method was used to select 50 small and medium business enterprises for their perspectives on the study's goals. The major research tool was the questionnaire, and the Statistical Package for Social Science (SPSS) was used to analyze the data collected in the field. COVID-19 appears to be taking a toll on the finances of small and medium-sized businesses that have made deals with SSNIT authorities to reschedule obligations related to default contributions, according to the findings. Although new projects have been placed on hold due to diminishing inflows, SSNIT's commitment to employees and payment of pensions to elderly residents remains unaffected. In light of the a fore mentioned challenges posed by the pandemic, the study suggested that the Government of Ghana should seek concessionary loans from world-class lenders such as the World Bank to strengthen its local stabilization fund and inject a significant amount of funds to assist struggling SMEs in resuming operations.
\end{abstract}

Keywords: Accra Metropolis, Business Operations, COVID-19, Pandemic, Social Security, Virus.

\section{Introduction}

The fact that humans become weaker as they age supports the idea that plans should be taken to ensure their survival after a productive existence on this planet. Workers' futures are secured through social security plans around the world as they reach senior citizenship age, which varies by country. Members must comply with the monthly contributions or premiums controlling the program for it to function successfully. Failure to contribute regularly hinders the growth of most of these social security channels, making it difficult to pay pensions and other stipends when they become due. As a result, legislative instruments have been proposed in most countries to ensure that such "premiums" are paid for the system to continue to work.

The system of social security, according to [1], constitutes the right of any human being and aligns with the needs of the universe for protecting employees against the likelihood of life risk and needs of society. For social security to be effective, it should be able to guarantee regular income to enable the senior citizen or retired person to live reasonably through decent accommodation, clothing well as feeding, and other social responsibilities. Social security schemes are essentially able to discharge the 
above responsibilities to their contributors through payment of monthly stipends and lump sums of money depending upon the terms of the policy within the pension scheme. Social security programmes can therefore be described [2] as an essential investment into the future of workers within the country to enable them to carry on with living conditions in their roles and those of their families as consumers. As a consumer, the worker will feed, clothe, shelter, and educate his or her dependents even after retirement. The scheme is an indispensable one that must be assisted to grow and flourish as planned. Concerning the additional importance of the social security system, one could say that it helps to enhance productivity while creating avenues for job openings, thereby enhancing the economic development of a country, to the enterprises and employers, social security assists in maintaining a quality workforce through reducing employee turnover necessary for building the kind of work teams that will be able to adapt to any changing situations and circumstances [3].

Another important aspect of a strong social security base is in the area of corporate social responsibilities, where the fund administrators often select human enhancement projects in education, health, shelter, etc., for financing. From the foregoing, one can effectively say that the social security programme is an attempt by the government to stabilize income levels when the employee either becomes incapacitated or approaches the mandatory retirement age yet still has to live on to respond to life patterns as he or she was doing whiles underemployment [4].

The social security system is certainly a welfare-stricken area that ensures the protection of people socially or an attempt to protect an individual from the vagaries of economic pressure after retirement or when an unexpected happens in the course of employment which could render the employee incapacitated [5]. Social security also acts as a protectionist measure to ensure that in the event of a death of a contributor, his or her dependents will continue to live by way of education, feeding, and sheltering through the receipt of pension funds slated for that purpose. Globally, social security conforms to an international convention established by the International Labour Organization (ILO) which expects every member country to put in place structures for protecting existing employees against hardships when they retire or when they suddenly become incapacitated as a result of an industrial accident or some social eventuality [6].

The advent of the COVID-19 pandemic appears to pose a threat to the various social security schemes globally, and for that matter, stakeholders ought to brainstorm on strategies for averting any future calamity that COVID-19 is likely to precipitate. The pandemic brought in its wake the need to change the work system and in some cases, close down entirely companies, thereby reducing their propensity to generate revenue to even pay workers let alone honouring their monthly social security contributions. Although legally, management members of companies are bound to make such regular contributions, the fact of the matter is that revenue levels continue to dwindle so badly that workers emolument could hardly be met, let alone make arrangements to pay for their social security contributions.

COVID-19 could be described as the third huge outbreak in the universe after SARS in the year 2003 and MERS, which also came around 2012. Although these previous outbreaks also had the potential of creating a serious impact on the health of global citizens in addition to the serious effect on economies, COVID-19 has sharpened and influenced the way business is conducted and even gotten policymakers to sit up and change the way things were done to survive under the menace of the pandemic [7]. Companies had to run shifts while others had to work from home without supervision, yet, owing to information technology, monitoring was possible to meet targets towards enhancing the strategic direction of various organizations. 
COVID-19, in addition, brought untold additional costs to humanity in terms of efforts towards managing it while going about normal duties [8]. Organizations, for instance, had to incur additional costs in making provision for social distancing, procuring sanitisers, and in some cases providing nose or face masks to shield employees from the menace of contracting the virus from colleagues. With the future of the disease unknown, businesses continue to incur additional costs in making provisions to circumvent the dreadful effect of the virus [9]. Governments globally are doing well with containing the virus through nonpharmaceutical measures, especially advocacy on social distancing, use of nose masks, and handwashing, and these so far have proven to be effective [10]. COVID-19 is certainly affecting the liquidity and solvency levels of companies in meeting statutory obligations.

This study, therefore, attempted to investigate COVID-19 factors that are responsible for irregular contributions towards the Ghana National Social Security Insurance Scheme with the searchlight on contributors within the Accra business metropolis. Specific objectives of the study are:

1. To assess how COVID-19 is disrupting business operations within the Accra metropolis.

2. To investigate how the shortfall in revenue is affecting SSNIT operations.

3. To examine the effect of COVID-19 on the general wellbeing of the citizenry.

4. To explore strategies for accommodating the challenges confronting SSNIT amid the pandemic.

The paper is segmented into five main parts, notably the introduction which contains brief literature on social security and COVID-19. The second part examines the research methodology employed to conduct the study. The third segment presents and analyzes the results of the study, while the fourth part discusses the findings. The fifth segment concludes the paper while making appropriate recommendations in light of the challenges uncovered with how the COVID-19 pandemic is frustrating efforts at paying social security contribution premiums.

\section{Research Methodology}

\section{Study Area: Accra Business Metropolis}

The study took place at Accra business metropolis, where the recent population census indicates a population of 5.4million. Accra is the capital region of Ghana and harbours the offices of all the foreign missions by way of embassies, high commissions in Ghana. It also has the headquarters of all government ministries, commercial banks, insurance companies, mining companies, petroleum companies, the merchandise industries as well as the transport sectors of the economy. Business prospects can therefore be said to be very brisk in this area, with small, medium, and large-scale companies in addition to multinationals all pitching their tents to compete effectively. Also in this area are the headquarters of some UN regional organizations, reputable NGOs, some international universities, as well as local tertiary institutions and training centres.

\section{Sampling Technique}

The study employed a random sampling technique to select six of the nineteen metropolitan and municipal assemblies in the Accra business region. These are Ablekuma Central Municipal, Accra Central, Ayawaso Central Municipal, Korle Klottey Municipal, La Dadekotopon Municipal, and Ledzokuku Municipal, from which small and medium scale enterprises were picked up through purposive sampling technique, to enable the views of their officials to be solicited for addressing the objectives of the study as shown in Table 1 . The latter also indicates that for each of the 50 companies, 3 persons made up of the owner, the manager, and the accountant were interviewed.

The purposive sampling technique also enabled the study to interact with some key officers at the headquarters of SSNIT in the Ministries region in Accra Central. Care was 
exercised to ensure that various industries i.e., service, manufacturing, extractive, energy, education, hospitality, etc., were all included in the sample to ensure a sound representation of companies for a fair generalization of findings.

Table 1. Distribution of Respondents

\begin{tabular}{|l|l|l|l|l|l|}
\hline Municipality & No. of Businesses & Owners & Officials & Frequency & Percentage \\
\hline Ablekuma Central & 8 & 8 & 16 & 24 & 16.0 \\
\hline Accra Central & 10 & 10 & 20 & 30 & 20.0 \\
\hline Ayawaso & 8 & 8 & 16 & 24 & 16.0 \\
\hline Korle Klottey, Osu & 8 & 8 & 16 & 24 & 16.0 \\
\hline La Dadekotopon & 8 & 8 & 16 & 24 & 16.0 \\
\hline Ledzokuku & 8 & 8 & 16 & 24 & 16.0 \\
\hline Total & $\mathbf{5 0}$ & $\mathbf{5 0}$ & $\mathbf{1 0 0}$ & $\mathbf{1 5 0}$ & $\mathbf{1 0 0}$ \\
\hline
\end{tabular}

Source (Researcher's Estimation, 2021)

\section{Sources of Information}

Information for the study emanated from both secondary and primary data, with secondary data emanating from internet sources, published papers, articles as well as SSNIT company files. The primary data was obtained from information gathered through interaction with selected respondents within the study area.

\section{Research Instrument}

The questionnaire technique constituted the main research instrument, although face-to-face techniques and interview guide helped in certain areas where the respondents had challenges with the English language. By way of questionnaire administration and data collection strategy, two weeks were agreed upon, within which each respondent was expected to finish completing the questionnaire.

\section{Data Collection and Analysis Strategy}

Through the telephone, the researcher monitored the respondent for the period that the questionnaires were in their domain until the due date for collection. Care was exercised to ensure that all areas of the questionnaire were answered except areas that did not apply to the respondent. The Statistical Package for Social Sciences (SPSS) facilitated the analysis of data captured from the field. The formula propounded by Slovin in respect of calculating the minimum size of sample i.e., $\mathrm{n}=\mathrm{N} /\left(1+\mathrm{Ne}^{2}\right)$ where $\mathrm{n}$ is the sample size, $\mathrm{N}$ is the population size and e i.e., the margin of error used, was used in securing the 150 sizes of the sample, out of which 136 questionnaires were retrieved thereby registering a response rate of $90.67 \%$.

\section{Ethical Consideration}

All respondents volunteered their readiness to assist the study with no one being coerced or put under some kind of duress to give responses in any direction. No embarrassing questions were asked, nor were any sensitive issues touched on, and for that matter, respondents were free to offer responses based on their own volition. Accordingly, the study can be said to be ethically upright.

\section{Results}

Displayed under this segment are the results gathered from the field study in respect of the objectives of the study. The arrangements have been done in the order of the objectives of the research.

\section{COVID-19 and its Effect on Businesses in Accra}

Depicted in Table 2 is information gathered from the field concerning the first objective of assessing how COVID-19 is disrupting business operations within Accra Metropolis. 
COVID-19 Effect on Business Operations in Accra Business District
COVID-19 have affected the general investment of SSNIT.

Shown in Table 2 are the results on how

Table 2. Frequency Table showing the Effect of Covid-19 on Business Operations

\begin{tabular}{|l|l|l|l|l|l|}
\hline Statements & $\mathbf{N}$ & Mean & STD Dev & Variance & Rank \\
\hline $\begin{array}{l}\text { Revenue has reduced owing to citizens being cautious of } \\
\text { coming out to do business }\end{array}$ & 136 & 4.072 & 0.597 & 0.356 & 1 \\
\hline $\begin{array}{l}\text { Business operations have slowed down because of the } \\
\text { reduction in working hours }\end{array}$ & 136 & 3.890 & 1.023 & 1.046 & 2 \\
\hline $\begin{array}{l}\text { Suppliers are not forthright with supplies because COVID has } \\
\text { changed their production patterns }\end{array}$ & 136 & 3.861 & 0.838 & 0.702 & 3 \\
\hline $\begin{array}{l}\text { Banking operations have also slowed down, and this is } \\
\text { affecting cash administration }\end{array}$ & 136 & 3.644 & 0.977 & 0.955 & 4 \\
\hline $\begin{array}{l}\text { Owing to COVID-19 protocols, production plant size activities } \\
\text { are slowly leading to a reduction in the production targets }\end{array}$ & 136 & 3.610 & 1.037 & 1.075 & 5 \\
\hline $\begin{array}{l}\text { Deliveries through motorbikes have also slowed down as a } \\
\text { result of the COVID-19, thereby reducing sales }\end{array}$ & 136 & 3.570 & 1.185 & 1.404 & 6 \\
\hline $\begin{array}{l}\text { Vendors or sales agents are no longer active because they claim } \\
\text { the market is slow thereby affecting revenue }\end{array}$ & 136 & 3.500 & 0.988 & 0.976 & 7 \\
\hline $\begin{array}{l}\text { Adequate revenue cannot be made through sales to motivate } \\
\text { employees to produce more }\end{array}$ & 136 & 3.430 & 0.909 & 0.826 & 8 \\
\hline $\begin{array}{l}\text { Poor revenue has resulted in the inability to meet liabilities as } \\
\text { and when they fall due on schedule }\end{array}$ & 136 & 3.395 & 1.195 & 1.428 & 9 \\
\hline
\end{tabular}

Source: (Field Data, 2021)

Table 2 features findings on how COVID-19 is affecting business operations in the Accra business district. The first ranking was the issue concerning the idea that "revenue has reduced owing to citizens being cautious of coming out to do business". The ranking second had to do with the statement that "business operations have slowed down because of reduction in working hours". The issue relating to "suppliers are not forthright with supplies because COVID has changed their production patterns" was third in the ranking. The fourth ranking happened to be the response that "banking operations have also slowed down, and this is affecting cash administration". The statement that "owing to COVID-19 protocols, production plant schedules are slow leading to a reduction in production targets" was 5th in the ranking. The sixth in the ranking was the response that "deliveries through motorbikes have also slowed down as a result of the COVID-19 thereby reducing sales". The seventh ranking with a mean score of 3.500, a standard deviation of 0.988 , and variance of 0.976 was the statement that "vendors or sales agents are no longer active because they claim the market is slow thereby affecting revenue". The idea that "adequate revenue cannot be made through sales to motivate employees to produce more" came eight. The $9^{\text {th }}$ ranking was the response that "poor revenue has resulted in an inability to meet liabilities as and when they fall due on schedule".

\section{Effect of COVID-19 on Company's Relationship with SSNIT in Terms of Contribution}

Shown in Table 3 are the results on the effect of COVID-19 on the company's relationship with SSNIT in terms of paying workers contributions. 
Table 3. Frequency Table showing the Effect of Covid-19 on SSNIT Contributions

\begin{tabular}{|l|l|l|l|l|l|}
\hline Statements & N & Mean & STD Dev & Variance & Rank \\
\hline $\begin{array}{l}\text { Low revenue and therefore inadequate funds to even pay } \\
\text { salaries }\end{array}$ & 136 & 3.876 & 0.777 & 0.558 & 1 \\
\hline $\begin{array}{l}\text { With low revenue being unable to cover salaries, it is } \\
\text { logical that SSNIT contribution cannot be paid }\end{array}$ & 136 & 3.790 & 1.019 & 1.038 & 2 \\
\hline $\begin{array}{l}\text { Change in production arrangement as a result of COVID- } \\
19 \text { has reduced the revenue base leading to inability to } \\
\text { motivate staff let alone paying SSNIT contribution }\end{array}$ & 136 & 3.710 & 0.886 & 0.785 & 3 \\
\hline $\begin{array}{l}\text { As a result of COVID-19, the company registers low } \\
\text { patronage, and this affects the ability to meet human } \\
\text { resource costs which include SSNIT contribution }\end{array}$ & 136 & 3.670 & 1.029 & 1.059 & 4 \\
\hline $\begin{array}{l}\text { We have to close down operations owing to COVID-19 } \\
\text { and therefore no revenue is generated for even paying } \\
\text { salaries let alone SSNIT contribution }\end{array}$ & 136 & 3.560 & 1.294 & 1.673 & 5 \\
\hline
\end{tabular}

Source (Field Data, 2021)

Presented in table 3 are responses on the effect of COVID-19 on the company's relationship with SSNIT in terms of the ability to honour monthly contributions. The first in the ranking was the response that "low revenue and therefore inadequate funds to even pay salaries". Ranking second was the response that "with low revenue, which is not able to cover salaries, it is logical that SSNIT contribution cannot be paid". The statement that "change in production arrangement as a result of COVID-19 has reduced the revenue base leading to inability to motivate staff let alone paying SSNIT contribution" registered the third position. The $4^{\text {th }}$ ranking in terms of popular response was that "as a result of COVID-19, the company registers low patronage, which affects the ability to meet human resource cost, including SSNIT contribution". Ranking $5^{\text {th }}$ in terms of responses was the statement that "we have to close down operations owing to COVID-19 and therefore no revenue is generated for even paying salaries let alone SSNIT contribution".

\section{Objective Two i.e., Shortfalls in Revenue and their Effect on the Operations of SSNIT}

An interview with SSNIT officials at the head office in Accra at the Ministries area made very interesting revelations. It came out that revenue by way of contributions from the informal sector has reduced appreciably over the last two years within the pandemic COVID-19 period largely owing to slow down in business and closure of some business concerns, especially in the hospitality industry for close to one year. Although food joints, hotels, drinking spots have resumed operations, revenue generation continues to be low owing to poor patronage. SSNIT is liaising with the owners of such establishment for rescheduling of premium payment except in cases where employees had been dismissed. According to the SSNIT officials, some private schools that were also affected by the government shutdown order following the pandemic have also been in negotiation with SSNIT with the view to restructuring unpaid premiums throughout the shutdown. SSNIT indicated that the government was in the process of creating a bailout fund to cushion most of these companies in the private sector affected by the shutdown directive.

It also came out from discussions with SSNIT officials that a reduction in revenue for the period means new investment projects would have to wait until funds are available. The sources explain that the SSNIT board often comes out with directives in respect of new 
investment outplays to broaden the scope of the company's investment portfolio, and these are usually quoted in the annual budget. Projects earmarked for investments within the COVID19 period had to wait to owe to drop in revenue generation emanating from the COVID regime. The officials noted that as soon as the fund level improves, management will not hesitate to carry out such new investments. Perhaps it might be worth mentioning that such investments are strategically conducted in blue-chip areas with the view to generating good income to accommodate payment of pension claims and other lump sum funds to beneficiaries.

It came out from the interview with SSNIT officials that employees' emolument is not being affected by the reduction in revenue as a result of the COVID-19 pandemic because adequate reserves have been built over the years to strengthen the financial base of the Trust and, for that matter, their financial situation is resilient and robust enough to ward off any "attack" from COVID-19 pandemic and its ramifications.

It is also reassuring to note that payment of ongoing pensions has also not been affected in any way by the COVID-19 pandemic. This, the officials explained, has been made possible owing to the strong financial base of the organization. The officials also confirmed the fact that the SSNIT investment base remains strong against the effect of the COVID-19 pandemic effect, and for that matter, employees and contributors have nothing to worry about in respect of the financial strength of the Trust. The officials, however, admitted that dividends from investments reduced slightly owing to a fall in revenue and profits of those establishments in which investments were made. It is pertinent to understand that SSNIT has investment as shareholders in a good number of formal private sector companies like commercial banks, insurance companies, manufacturing concerns, oil companies who pay dividends to SSNIT from their profit and, therefore reduction in profit and revenue could also mean reduction in dividend levels. From time to time, SSNIT invests in some social projects such as renovating schools, hospitals, sponsoring tree planting exercises, etc., under its corporate social responsibility agenda. Owing to a fall in revenue as a result of COVID-19, SSNIT is unable to adequately handle such planned projects, although management hopes to reactivate most of these undertakings as soon as the income stream stabilizes.

On challenges facing some informal sector companies in paying a premium as a result of a drop in revenue, officials explained that SSNIT has entered into an arrangement to reschedule payment of premium for staff who are still working with such companies. This source explains it is a long-standing management policy of going to the aid of struggling companies even before the advent of the COVID-19 pandemic.

\section{Discussion of Findings}

This segment of the article discusses the findings by examining how they compare with or defer from existing contemporary literature on the subject of COVID-19 and its effect on business revenue as well as socio-economic life. The discussions have been conducted in the order of the research objectives. On objective one of assessing how COVID-19 is disrupting business operations within Accra Metropolis, it came to light that generally, the revenue base of companies has drastically reduced owing to citizens being cautious of coming out to do business. Studies confirmed these findings and pointed out that citizens are sceptical in going about general social life and therefore, the propensity to spend has been reduced markedly, leading to shortfalls within revenues of operators within the commercial centres [11]. Another finding that "business operations have slowed down because of reduction in working hours" has also been confirmed in a study which indicated that with the restructuring of business operations within factory floors, banking halls, back-office activities, etc. the number of workers had been reduced leading to a reduction in productive hours and by extension companies 
output which translates into revenue reduction for a good number of business operators [12]. The source continues that some resorted to running shifts to make room for the shortfall, yet it turned out that the shortfall was still registered owing to caution and the need to observe COVID-19 protocols, especially the frequent washing or sanitizing of hands. The discovery that suppliers delay with their supplies because COVID-19 has made it necessary for manufacturers to change their production patterns has also been mentioned in a similar study [13]. The source noted that changes in work patterns affect suppliers leading to delay in meeting orders. Findings that reduction in revenue is disrupting efforts at motivating employees to perform has also been corroborated in a paper on a similar study. The latter noted that even some employers in the SME sector have challenges in meeting the basic salary, let alone making enough to meet bonuses and other performance enhancement emolument. Another finding which has been widely published has to do with the fact that "poor revenue has resulted in the inability to meet liabilities as and when they fall due or on schedule". A study noted that this challenge is really disrupting a good number of business activities and therefore slowing down operations and affecting productivity. The good news according to the source however is that people understand the situation and therefore readily agree to reschedule debt payment as it is in the case of SSNIT which has agreed to allow a good number of small and medium-sized enterprises adequate time to pay continuing employees contribution using a rescheduled payment scheme [14].

On how the COVID-19 pandemic is disturbing the relationship between SSNIT and its developing partners especially the SME sector, the study noted that "low revenue and therefore inadequate funds to even pay salaries" continue to be the slogan for a large segment of these businesses. This finding is supported by a study that noted that, in situations where even salaries cannot be met by existing low revenue, it is only logical that such business establishment will default in payment of SSNIT contributions [15]. The source advised business owners to talk to SSNIT about the way forward since the circumstances are beyond their control. The finding that "as a result of COVID-19, the enterprise registers low patronage and this affects the ability to meet human resource cost which includes SSNIT contribution" makes it mandatory for SME business owners to speak to SSNIT on how their predicament can be addressed in terms of monthly contributions [16]. The source explains further that it behoves every creditor to examine the situation carefully and see how to help the debtor with means of deferring payment to maintain the business relationship. Another study supports the finding that companies have "to close down operations owing to COVID-19 and therefore no revenue is generated for even paying salaries let alone SSNIT contribution" and indicates that the COVID situation is an anti-business climax and for that matter, stakeholders ought to put their shoulders on the wheel to find an amicable way forward for all to survive.

The second objective sought to investigate how shortfalls in revenue are affecting SSNIT operations. The finding that "revenue by way of contributions from the informal sector has reduced appreciably over the last two years within the pandemic COVID-19 period" has been confirmed by a study that noted that most statutory organizations that receive periodic payment are all reporting a decline in their revenue mobilization effort [17]. The source also pointed to a jaw-jaw approach towards ensuring an amicable way forward. Another finding which has been supported by existing literature has to do with the notion that "reduction in revenue for the period means new investment projects would have to wait until funds are available". This, the study explains, is a general finance issue and that when no funds are available for a project, it has to be put on hold until prospects for securing funds are higher, 
then; initiatives will have to be made towards commencing the project. The study further noted that with COVID-19 around, a lot of projects are suffocating in terms of financing, and for that matter, there is the need to defer such project progressions until revenue streams appreciate tremendously to accommodate the execution of such projects [18]. The findings that "SSNIT workers' emolument has not been affected by the reduction in revenue" has been supported by a study which observed in a financial article that generally, public sector subvented institutions remain strong and resilient during periods of a general drop in revenues because they receive budgetary support which covers at least one year's expenditure which includes HR cost [19]. Another study, however, is of the view that should the COVID situation become serious and lockdown inevitable for a long period, then even strong public institutions will sense their limitations with continued payment of emolument [20]. The source, therefore, advises the public to endeavour to stick to the WHOapproved COVID-19 protocols to minimize the spreading menace of the disease, thereby keeping it under control and eventually wiping it off the surface of the earth. This way, business activities will bounce back to normal for all to enjoy an ordinary business environment towards enhancing socio-cultural and economic living systems. The study also found out that "SSNIT investment base remains resilient and robust against the effect of COVID-19 pandemic effect" and additionally, "payment of ongoing pensions have also not been affected in any way by the COVID-19 pandemic". The financial strength of public sector funds collection agencies like banks, insurance companies, SSNIT, etc., cannot easily be eroded by periods of pandemics unless such unfortunate events propagate for long periods over five years [20]. The source notes that investments made by such organizations are often solid and liquid enough to accommodate shortfalls within a mediumterm period to five years, and for that matter, for such organizations to be "wounded" financially would mean long-term devastation on their financial inflows. One study also supported this view and noted that commercial banks and insurance companies need not have challenges in meeting customers' demands, such as paying pensions or payment in respect of cheque withdrawals since adequate provisions have already been made for accommodating such contingencies. These sources indicate that when pandemics propagate for a much longer period, then the financial muscles of these statesupported organizations and strong formal private sector players will sense their limitations in honouring their core mandates. Here, the views in an article that all must cooperate towards eliminating the menace of COVID-19 should be relevant to delve a devastating blow to the pandemic for mankind and business climate to be free for normalcy to return. The study also discovered that "dividends from investments however reduced slightly owing to fall in revenue of those establishments in which investments were made". This, another study explains, is a normal finance consequence and that when business operations slowdown in terms of revenue, profit is affected, leading to a reduction in all payments that depend upon profits especially dividends. This, therefore, suggest that it is not surprising that SSNIT's income on investment has begun to show a downward trend. It is equally reasonable that "SSNIT investments to Corporate Social Responsibilities (CRS) projects have been reduced as a result of low revenue over the last two years". This, the source explains, is a financial consequence because SSNIT's core mandate excludes CRS activities. It is therefore only logical for the Trust to wait until conditions are favourable before helping the needy through its corporate social responsibility outlet.

The third objective sought to examine the effect of COVID-19 on the general wellbeing of the citizenry and noted that the government's spending arm has been "wounded" as a result of fallen tax revenue and that "planned employment of teachers, nurses, regimental 
sector officials, doctors, civil servants have to be put on hold". This, according to a study, is normal with most countries under the COVID19 period since engaging new employees comes with financial commitment, which means adequate revenue must be available to cover salaries and other emoluments [21]. The findings that "planned payment to government contractors for jobs done in terms of additions and modernizations to infrastructure and social amenities had to be suspended" is also seen by a study as a general consequence since revenue projections in the annual budget did not materialize in full and for that matter government should have difficulty in meeting all these commitments [22]. The source continues that if the pandemic progresses for a longer period, then it may even be difficult to meet the salary and remunerations levels of existing state employees. The finding that "awarding of contracts for new schools, hospitals, road were all suspended" has been corroborated by an article which indicated that with the gestation period of COVID-19 being unknown, it is difficult for the Central Government to go into big projects which will depend mainly on Internally Generated tax funds [23]. The source continues that infrastructure projects in this COVID era will have to be funded by external injections such as loans from the international monitoring fund (IMF) or its commercial wing International Finance Corporation (IFC). Such loans are often sovereign guaranteed, and therefore, donors are not too worried about default in repayment. The finding that in times of lockdown, there is the need for government to find other revenue to feed vulnerable citizens have been supported by an article that noted that some citizens in the lower-income group live by hand to mouth on a daily basis and therefore restricting their movement denies them of access to menial jobs and the attendant revenue. This explains why some arrangements ought to be put in place towards feeding and possibly ensuring their comfort throughout the COVID lockdown period [24]. Additional existing literature which supports this view mentions the fact that in some western economies, payment of rent was even frozen for the lockdown period, and the government made arrangements to subsidize such payment in addition to dishing out living allowances. COVID-19 is certainly a "monster" which, if not eliminated in good time, could glide activities on the surface of the earth to a halt. It is therefore essential that all stakeholders, especially opinion leaders as well as citizens, come on board and observe basic WHO protocols towards preventing contact with the virus to stem the tide of the spread, for mankind to be free and live peacefully as before on the surface of this God-given planet earth [25].

\section{Conclusions and Recommendations}

\section{Conclusions}

The study set out to examine the factors which contributed towards non-compliance of Social Security monthly contribution Payments in Ghana as a result of the advent of COVID-19, with the searchlight on 50 small and medium scale enterprises in the Accra Business Metropolis. It can be concluded from the field study that COVID-19 is responsible for low revenues registered by the operators of both formal and informal business sectors as well as statutory revenue collection agencies like SSNIT and Ghana Revenue Authority (GRA). SSNIT's payment of pensions and workers' emolument has not been disrupted by default in payment of monthly contributions, although its dividends by way of income from investments have shown a downward trend as a result of the dwindling revenue base of the commercial sector precipitated by COVID-19. SSNIT is also slowing down with its commitment to CSR projects as a result of the COVID-19 pandemic. Management of SSNIT is in contact with business operators who are experiencing challenges in paying workers contribution with the view to working out a mutually beneficial strategy for the way forward. COVID-19 pandemic is a menace that should not be allowed to propagate further, and therefore all 
stakeholders and citizens must cooperate by observing the basic protocols recommended by WHO towards preventing contact with the virus. This way, socio-economic systems will bounce back to normalcy for small and medium scale enterprises to continue to meet their monthly contributions regularly towards strengthening the financial muscle of SSNIT.

\section{Recommendations}

Taking cognizance of the issues uncovered in the study with regards to difficulties encountered by business houses in honouring their monthly contributions to SSNIT the following recommendations are worth considering:

1. Government should strengthen and be forthright with its business stabilization fund and help all small, medium, and large companies that have financial difficulties as a result of COVID-19 to assist them to bounce back to business and enhance their capacity. This way adequate revenue will be generated to ensure reasonable profit necessary to facilitate payment of taxes and other commitments, including SSNIT monthly contributions.

2. In the case of some business segments, especially those in the hospitality sector like hotels, food joints, drinking pubs, educational institutions, etc. experiencing longer periods of shutdown resulting in very low revenue levels, it is recommended that government instructs the social security regulator i.e. National Pension Regulatory Authority (NPRA) to suspend the payment of employees' contribution until a later date when businesses stand on their feet and can adequately pay workers and by extension make provision for monthly SSNIT contributions.

3. Taking cognizance of the fact that the majority of the development partners of SSNIT are small and medium scale enterprises that are also experiencing difficulty in revenue levels as a result of the COVID-19 pandemic, it is only logical for the SSNIT board of directors to turn their attention towards financially retooling such small and medium scale enterprises through soft loans which can be monitored effectively to resuscitate these businesses towards standing on their feet and continue paying their monthly employee contributions.

4. Judging from the intense pressure on government spending arm as a result of additional COVID-19 burdens and dwindling inflows, it is only fair and reasonable that government solicits international soft loans from such friendly creditors like International Finance Corporation (IFC) of the World Bank for onlending to the private sector at highly concessional rate. Such medium to longterm loans will certainly help in reviving most of the "dying" business enterprises.

5. Given the recent hike in the death toll of Ghanaians from 550 to nearly 1,200 , it behoves the government to strengthen COVID-19 protocol arrangements to protect the citizenry from the deadly effect of the virus through close monitoring by the security agencies to ensure compliance with the basic protocols such as social distancing, washing of hands, wearing of a mask. This way, citizens will live to work longer hours to make more money, pay higher SSNIT contributions to strengthen the scheme.

\section{Limitations of the Study}

COVID-19 pandemic is a countrywide problem and taking cognizance of the fact that the country now has 260 politically segmented jurisdictions, notably Metropolitan, Municipal, and District Assemblies (MMDA), using only six (6) in an important study like this suggests that the information may not be adequate for addressing the objective of the study. Moreover, the fact that the study questioned respondents on their employee management costs suggested to some respondents that government could be behind the research, and this made them 
sceptical in volunteering certain kinds of information. This means that disclosures by way of information were carefully conducted, and for that matter, some details might have been withdrawn. This also discounts the adequacy of information for the study. The researcher, as a senior company official, a family person, and a $\mathrm{Ph} . \mathrm{D}$. finalist certainly has difficulty in finding adequate time and cash resources for a much bigger scale of study thereby limiting the research only to Accra. Irrespective of the above challenges, the researcher was certain of coming up with an article that will be acceptable by all as far as the effect of the COVID-19 pandemic on the payment of SSNIT monthly contribution is concerned.

\section{Conflict of Interest}

I, Samuel Nii Attoh Abbey, hereby declare that except for references to other authors' work which have been duly cited and recognized, this Article is the result of my work. It has neither in part nor in whole been submitted nor exhibited in any Institution for any academic purposes.

\section{References}

[1] International Labour Organisation (2015). International Labour Office World Labour Report 2015: Income Security and Social Protection in a Changing World. Geneva International Labour Office.

[2] Haaga, Owen, and Richard W. Johnson. 2012.

"Social Security Claiming: Trends and Business Cycle Effects". Working Paper No. 2012-5. Chestnut Hill, MA: Center for Retirement Research at Boston College.

http://crr.bc.edu/wpcontent/uploads/2012/02/wp2012-5508.pdf.

[3] McKinnon, R. (2005). Extending coverage and increasing security. In Social Security: Toward Newfound Confidence, Levinsky and McKinnon, eds. Geneva: International Social Security Association.

[4] Miller, Billie Jean, and Sylvester J. Schieber. 2014. "Contribution of Pension and Retirement

\section{Acknowledgement}

Several good people worked behind the scenes towards coming up with this article. First Messrs Duncan and Mensah Addo of the operations department of SSNIT head office, Accra ought to be commended for creating the environment for the researcher to interview some of their colleagues to secure their views on the rationale behind the study. Business owners within the decentralized governing structures like the Ablekuma Central Municipal, Accra Central, Ayawaso Central Municipal, Korle Klottey Municipal, La Dadekotopon Municipal, and Ledzokuku Municipal who made themselves available to be interviewed also deserve mention. Kingsley Adu Gyamfi of Trust Jubilee Consult must also be acknowledged for the expert manner in which he handled the stenography aspect of this article. God richly bless them all.

Savings to Retirement Income Security: More Than Meets the Eye". Journal of Retirement 1(3): 14-29.

[5] Bailey, C., \& Turner, J. (2001). Strategies to reduce contribution evasion in social security financing. World Development (February), 385-393. [6] Purcell, Patrick J. (2016). "Employment at Older Ages and Social Security Benefits Claiming." Social Security Bulletin 76(4): 1-17.

[7] Anderson, R. M., Heesterbeek, H., Klinkenberg, D., \& Hollingsworth, T. D. (2020). How will countrybased mitigation measures influence the course of the COVID-19 epidemic? The Lancet, 395(10228), 931934.

[8] Inoue, H., \& Todo, Y. (2020). The propagation of the economic impact through supply chains: The case of a mega-city lockdown against the spread of COVID-19. PlosOne, 15(9), e0239251 doi. 10.1371/journal.pone.0239251.

[9] Peter, D. (2020). COVID-19: The Social Implication of a Pandemic. Proshare Finance. The 
Guardian. Saturday, March 28, 2020. PRNigeria (2020). COVID-19: ABU ZariaScientistsProduce4in-1 Sanitizing Machine. https://prnigeria.com/2020/05/11/Abuzaria/sanitizin g-machine/. Accessed 24th May 2020.

[10]Dell'Ariccia, G., Mauro, P., Spilimbergo, A, and Zettelmeyer, J., 2020. Economic policy for the COVID-19 war. Retrieved from https://blogs.imf.org/2020/04/01/economicpolicies for the-COVID-19-war/, April, 2020

[11]Levinsky, R. (2005). Social security and labour market developments: Facilitating flexibility by strengthening security. In Social Security: Toward Newfound Confidence, Levinsky and McKinnon, eds. Geneva: International Social Security Association.

[12]Loayza, N., \& Pennings, S. (2020). Macroeconomic policy in the time of COVID-19: A primer for developing countries. World Bank Malaysia hub.

[13] Walmsley, T., Rose, A., \& Wei, D. (2020). Impacts on the U.S. Macro-economy of mandatory business closures in response to the COVID-19 pandemic. CREATE working paper. The University of Southern California.

[14] Gillion, C., Turner, J., Bailey, C., \& Latulippe, D. (Eds.) (2000). Social Security Pensions and Reform. International Labour Office, Geneva, Switzerland.

[15] McKibbin, W., \& Fernando, R. (2020). The global macroeconomic impacts of COVID-19: Seven scenarios. In CAMA working paper No.19/2020. Centre for Applied Macroeconomic Analysis, Australian National University.

[16]Maliszewska, M., M, A., \& van der Mensbrugghe, D. (2020). The potential impact of COVID-19 on GDP and trade. World bank policy research working paper No. 9211. Washington DC: World Bank.
[17]Barrientos, A., and P. Lloyd-Sherlock (2003). Non-contributory pensions and social protection. Issues in Social Protection Discussion Paper (Geneva: International Labour Office).

[18]Eichenbaum, M.S., Rebelo, S., \& Trabandt, M. (2020). The macroeconomics of epidemics, NBER Working Paper, No.26882. doi. 10.3386/w26882 [19] SSNIT (2002), Medium-Term Strategic Plan: 2002 - 2006, Social Security and National Insurance Trust (SSNIT), Accra, May 2002.

[20] WHO. (2020). Novel coronavirus (2019-nCoV) Situation Report - 1, 21 January 2020. Geneva: World Health Organization.

[21] Morgan, J.P. (2020). The fallout from COVID19: global recession, zero interest rates, and emergency policy actions. Accessed on June 4th, 2020. [Retrieved from].

[22] MoFEP, 2020. Statement to parliament on the economic impact of the COVID-19 pandemic on the economy of Ghana. Retrieved from https://mofep.gov.gh/index.php/news-andevents/2020-03-30/statement-to-parliament-oneconomic-impact-of-the-covid-19-pandemic-on-theeconomy-of-ghana, March 2020.

[23] IMF. (2020). World Economic Outlook: The Great Lockdown. International Monetary Fund, Washington DC.

[24] Atkeson, A. (2020). What will be the economic impact of COVID-19 in the US? Rough estimates of disease scenarios. NBER Working Paper, No.26867. doi. 10.3386/w26867 Economic Commission of Africa (2020). Trade policies for Africa to tackle COVID-19. [Retrieved from].

[25] Hamzelou, J. (2020). UK's scientific advice on coronavirus is a cause for concern. New Scientist, 245(3275), 9. $\quad$ https://doi.org/10.1016/S02624079(20)30613-8. Online. 3275. 